\title{
Experimental Study of Thin Steel Tubes Welded by Fiber Laser
}

\author{
Dana Bakošová, Alžbeta Bakošová
}

Faculty of Industrial Technologies in Púchov, Alexander Dubček University of Trenčín. I. Krasku 491/30, 020 01 Púchov. Slovakia.E-mail: dana.bakosova@tnuni.sk, alzbeta.bakosova@student.tnuni.sk

The laser welding method is one of the youngest but the most progressive welding methods. The advantages of laser welding include: simple automation combined with modern computer technology, very low heat input to the weld, high productivity, high welding accuracy and low noise during laser operation. In this work, the sample meltings were prepared in a protective atmosphere varying the welding parameters - laser power, welding speed, or focus position. A total of 12 samples were prepared this way. The aim was to evaluate the shape and depth of the melting of the material for selected values of parameters. Based on this metallographic evaluation, the optimal welding parameters were selected for a pair of austenitic stainless steel tubes (X2CrNi19-11 and X5CrNiMo17-12-2) for fiber laser welding. Macrostructure and microstructure evaluations, microhardness tests and tensile tests were performed on these welded samples.

Keywords: steel, fiber laser, microhardness, weld, metallography

\section{Introduction}

Welding is one of the most demanding uses of a laser beam. A laser is a quantum light beam generator that is used to amplify light waves through stimulated radiation emission [1]. The radiation comes from a laser in the form of a monochromatic (single-wavelength) or coherent (phase-matched) beam that has a high energy density [2]. From a design point of view, lasers are divided into several types, of which solid-state lasers (eg Nd-YAG), gas (eg $\mathrm{CO}_{2}$, excimer) and semiconductor (diode) lasers are mainly used for welding.

Advantages of laser welding [3]:

- High power density on the impact surface minimal deformation of the material.

- High welding speed as heat passes through the material in a very short time.

- The energy of the laser beam is able to melt any known material.

- Thermal energy is transferred to the material in only a few milliseconds, which allows welding even near to heat-sensitive materials (glass, plastics).

- Welds have high strength and they are free of pores.

- Deep welds can be made effectively up to a material thickness of $25 \mathrm{~mm}$ [4].

- The laser beam can weld locally hard-to-reach places that would not otherwise be possible to weld at all.
The area of laser welding application includes processing of different types of materials: metals and their alloys, ceramics, polymers and composites. Limitation of the disadvantages of technological use of lasers welding in some applications, for example the small width of weld, can be obtained by combining it with other heat sources such as active gas arc welding (MAG) and laser- tungsten inert gas arc welding (TIG) to create hybrid processes [5]. Laser welding of high-alloy steels, especially stainless steels is often used.

Austenitic steels are widely used high-alloy stainless steels that find application in many industrial sectors including chemical industry, pharmaceutical industry, food processing, as well as power generating plants. Due to the content of chromium (above 18\%) and nickel (minimum 8\%) these steels have high corrosion resistance and good structure stability. Alloying elements such as titanium, molybdenum and niobium can be added to these alloys in order to further improve their properties. Besides high corrosion resistance Austenitic steels are characterized by good strength and plastic parameters. They are considered to have good weldability. The main problems associated with the welding process are the preservation of corrosion resistance and hot cracking [6]. General information about welding of stainless steel can be found, among others, in a lot of scientific reports $[7$, $8,9,10]$.

Kumar et al. [11] investigated the effects of laser power, scanning speed and pulse width on the tensile strength and weld width of welded stainless steel sheets made of AISI 304 and AISI 316. Berretta et al. [12] have investigated laser welding of stainless steel AISI 
304 to AISI 420. Landowski et.al presented in study [5] results of experimental tests on quality of dissimilar welded joints between austenitic steel 316L and 2304 lean duplex stainless steel. Effect of incident angle on the weld pool geometry, microstructure and tensile property of the welded joints was presented by Kumar et al. in [13]. Sathiya et al. [14] studied optimization of laser welding process parameters for austenitic stainless steel using artificial neural networks and genetic algorithm. Tsirkas et al. [15] have developed a three dimensional finite element model for laser welding. Tam et al. presented in [16] the multi-scale model applied to simulate multiple cases of different welding parameters. Suder and Williams analysed in [17] effects of laser power, welding speed and beam diameter on depth of penetration and weld profile in order to create empirical model that enables achievement of a particular depth of penetration independent of the laser beam diameter. Olabi et al. [18] have studied the dissimilar full-depth laser-butt welding of austenitic steel AISI 316 and low carbon steel using $\mathrm{CW} 1.5 \mathrm{~kW} \mathrm{CO}$ laser. The effect of welding speed, laser power and focal point position on mechanical properties and on the operating cost has been also investigated in this study. Optimization of $\mathrm{CO}_{2}$ laserwelding process of austenitic stainless steel was also investigated in [19].

\section{Material and methods}

Austenitic chromium-nickel steel X2CrNi19-11 has increased resistance to intergranular corrosion (extremely low carbon content). The material is weldable, very easy to polish and has good cold formability, it has good thermal stress resistance and it is usable up to $400{ }^{\circ} \mathrm{C}$. This steel is suitable for use in the engineering industry, food and pharmaceutical industries, in the production of surgical equipment etc. The properties of steel X2CrNi19-11 are listed in the Tables 1 to 3.

Tab. 1 Chemical composition of steel X2CrNi19-11

\begin{tabular}{|c|c|c|c|c|c|c|}
\hline $\mathbf{C}$ & $\mathbf{M n}$ & $\mathbf{P}$ & $\mathbf{S}$ & $\mathbf{S i}$ & $\mathbf{C r}$ & $\mathbf{N i}$ \\
\hline $\max 0.03 \%$ & $\max 2 \%$ & $\max 0.045 \%$ & $\max 0.03 \%$ & $\max 1 \%$ & $17-20 \%$ & $10-12.5 \%$ \\
\hline
\end{tabular}

Tab. 2Mechanical properties of steel X2CrNi19-11

\begin{tabular}{|c|c|c|c|c|}
\hline $\begin{array}{c}\text { Tensile strength } \\
\mathbf{R}_{\mathbf{m}} \mathbf{( M P a )}\end{array}$ & $\begin{array}{c}\text { Yield strength } \\
\left.\mathbf{R}_{\mathbf{p}} \mathbf{0 . 2} \mathbf{0} \mathbf{( M P a}\right)\end{array}$ & $\begin{array}{c}\text { Ductility } \\
\mathbf{( \% )}\end{array}$ & $\begin{array}{c}\text { Hardness } \\
\text { HRB }\end{array}$ & Structure \\
\hline $520-660$ & 175 & 45 & $\max 88$ & Austenitic \\
\hline
\end{tabular}

Tab. 3 Other properties of steel X2CrNi19-11

\begin{tabular}{|c|c|c|c|}
\hline Weldability & Ductility, malleability & Corrosion resistance & Thermal resistance \\
\hline Very good & Good & Excellent & Up to $400{ }^{\circ} \mathrm{C}$ \\
\hline
\end{tabular}

$\mathrm{X} 5 \mathrm{CrNiMo17-12-2}$ is austenitic acid-resistant chromium-nickel-molybdenum steel with increased corrosion resistance (increased molybdenum content), with good weldability. The main alloying components are $\mathrm{Cr}, \mathrm{Ni}$ and Mo., It is resistant to intergranular corrosion after welding up to a thickness of $6 \mathrm{~mm}$ even without additional heat treatment due to low carbon content. It is used in applications where components and devices are exposed to water, water vapour and air humidity, for the manufacture of fittings, pumps, medical and surgical instruments, etc. The properties are listed in the Tables 4 to 6.

Tab. 4 Chemical composition of steel X5CrNiMo17-12-2

\begin{tabular}{|c|c|c|c|c|c|c|}
\hline $\mathbf{C}$ & $\mathbf{M n}$ & $\mathbf{P}$ & $\mathbf{S}$ & $\mathbf{S i}$ & $\mathbf{C r}$ & $\mathbf{N i}$ \\
\hline $\max 0.07 \%$ & $\max 2 \%$ & $\max 0.045 \%$ & $\max 0.03 \%$ & $\max 1 \%$ & $16.5-18.5 \%$ & $2-2.5 \%$ \\
\hline
\end{tabular}

Tab. 5Mechanical properties of steel X $5 \mathrm{CrNiM017-12-2}$

\begin{tabular}{|c|c|c|c|c|}
\hline $\begin{array}{c}\text { Tensile strength } \\
\mathbf{R}_{\mathbf{m}} \mathbf{( M P a )}\end{array}$ & $\begin{array}{c}\text { Yield strength } \\
\mathbf{R}_{\mathbf{p}} \mathbf{0 . 2 \%} \mathbf{( M P a )}\end{array}$ & $\begin{array}{c}\text { Ductility } \\
\mathbf{( \% )}\end{array}$ & $\begin{array}{c}\text { Hardness } \\
\text { HRB }\end{array}$ & Structure \\
\hline $540-680$ & 205 & 40 & $\max 95$ & Austenitic \\
\hline
\end{tabular}

Tab. 6 Other properties of steel X5CrNiMo17-12-2

\begin{tabular}{|c|c|c|c|}
\hline Weldability & Ductility, malleability & Corrosion resistance & Thermal resistance \\
\hline Very good & Good & Excellent & Up to $400^{\circ} \mathrm{C}$ \\
\hline
\end{tabular}


Laser welding scheme - a laser beam provides to melt and evaporate the material. It is focused to a small point. Laser welding can be performed in two ways. In conduction mode with a larger beam diameter and its lower power heat from the surface is transferred to the material by means of thermal conductivity [20]. This is typical of low power Nd: YAG laser welding with relatively shallow welds. Keyhole mode is high-power laser welding, characterized by the formation of a deep and narrow crater filled with metal vapour gases called a steam-gas tunnel, which viewed from above has the shape of a key-hole, at the point of interaction of the beam with the material [21]. The energy of the laser melts and evaporates the metal as the laser beam moves. The vapour pressure displaces the molten metal so that at the back of the weld pool, the metal solidifies to form a weld [22]. It supports the transfer of laser energy to the metal and directs the laser beam deep into the material. This makes it possible to obtain very deep and narrow welds and that is why this welding is also called deep penetration welding. The laser can be welded in an air atmosphere or in a special working atmosphere [23]. Welding gases must meet several requirements - protection of the weld pool and the heat-affected zone, protection of the optics against smoke and spatter, root protection and plasma control during $\mathrm{CO}_{2}$ laser welding [24].

\section{Experimental part}

The experiment was focused on the use of fiber laser welding with a rotary axis and shield gas argon, for thin metallic materials. The aim was to make welds and evaluate their shape and depth for selected values of parameters. Exanimated parameters included welding speed, laser power and focus position. Welds were made on 12 samples from steel X5CrNiMo1712-2 tubes with a diameter of $3 \mathrm{~mm}$. After evaluating the welds, a pair of tubes was welded with selected optimal parameters. A $2 \mathrm{~mm}$ diameter pipe made of steel $\mathrm{X} 2 \mathrm{CrNi19}-11$ was inserted into a $3 \mathrm{~mm}$ pipe made of X5CrNiMo17-12-2 steel. To determine the quality of welds, we used a tensile test, a Vickers microhardness, macrostructure and microstructures evaluation of welds. The parameters of the fiber laser, together with the parameters of the focusing optics, which were used for the production of welds and the measured values of the depth of welds, are listed in Tables 7 and 8.

\section{Tab. 7 Settings of constant parameters of welding equipment}

\begin{tabular}{|c|c|c|c|c|c|}
\hline $\begin{array}{c}\text { Welding } \\
\text { power } \\
\mathbf{P}(\mathbf{W})\end{array}$ & $\begin{array}{c}\text { Laser } \\
\text { wavelength } \\
(\boldsymbol{\mu m})\end{array}$ & $\begin{array}{c}\text { Beam } \\
\text { parameter } \\
\mathbf{M}_{\mathbf{2}}\end{array}$ & $\begin{array}{c}\text { Focal length } \\
\text { of the lens } \\
\mathbf{F}(\mathbf{m m})\end{array}$ & $\begin{array}{c}\text { Beam diame- } \\
\text { ter in front of } \\
\text { the lens } \\
\mathbf{D}(\mathbf{m m})\end{array}$ & $\begin{array}{c}\text { Beam diame- } \\
\text { ter in the focal } \\
\mathbf{D}_{\mathrm{F}}(\boldsymbol{\mu m})\end{array}$ \\
\hline 120 & 1.069 & 1.4 & 150 & 5 & 57.195 \\
\hline
\end{tabular}

Tab. 8 Welding parameters used for the samples and depth of the created welds

\begin{tabular}{|c|c|c|c|c|c|c|c|}
\hline $\begin{array}{c}\text { Sample } \\
\text { name }\end{array}$ & $\begin{array}{c}\text { Focal } \\
\text { location } \\
\mathbf{L}(\mathbf{m m})\end{array}$ & $\begin{array}{c}\text { Welding } \\
\text { speed } \\
\left.\mathbf{V}_{\mathbf{z}} \mathbf{( m m} / \mathbf{s}\right)\end{array}$ & $\begin{array}{c}\text { Beam } \\
\text { diameter } \\
\mathbf{d}_{\mathbf{L}}(\mathbf{m m})\end{array}$ & $\begin{array}{c}\text { Intensity } \\
\mathbf{I}_{\mathbf{m}} \\
\mathbf{W} / \mathbf{m m}^{2} \mathbf{)}\end{array}$ & $\begin{array}{c}\text { Time of } \\
\mathbf{e x p o s u r e} \\
\mathbf{t}(\mathbf{m s})\end{array}$ & $\begin{array}{c}\text { Energy } \\
\text { density } \\
\mathbf{E}_{\mathbf{m}} \\
\left(\mathbf{J} / \mathbf{m m}^{2}\right)\end{array}$ & $\begin{array}{c}\text { Depth of } \\
\text { the weld } \\
\mathbf{h}(\mathbf{m m})\end{array}$ \\
\hline $\mathbf{A 1}$ & 6 & 26.17 & 0.255 & 1960.50 & 9.74 & 19.099 & 0.381 \\
\hline $\mathbf{A 2}$ & 5 & 26.17 & 0.222 & 2585.83 & 8.48 & 21.934 & 0.571 \\
\hline $\mathbf{A 3}$ & 4 & 26.17 & 0.189 & 3566.09 & 7.22 & 25.758 & 0.588 \\
\hline $\mathbf{A 4}$ & 4 & 26.17 & 0.189 & 4279.31 & 7.22 & 30.910 & 0.569 \\
\hline $\mathbf{A 6}$ & 7 & 26.17 & 0.288 & 1537.34 & 11.00 & 16.912 & 0.095 \\
\hline $\mathbf{A 7}$ & 7 & 31.40 & 0.288 & 1537.34 & 9.17 & 14.094 & 0.086 \\
\hline $\mathbf{A 8}$ & 6 & 31.40 & 0.255 & 1960.50 & 8.12 & 15.915 & 0.221 \\
\hline $\mathbf{A 9}$ & 5 & 31.40 & 0.222 & 2585.83 & 7.07 & 18.278 & 0.361 \\
\hline $\mathbf{A 1 0}$ & 4 & 31.40 & 0.189 & 3566.09 & 6.02 & 21.465 & 0.518 \\
\hline $\mathbf{B 1}$ & 4 & 31.40 & 0.189 & 4279.31 & 6.02 & 25.758 & 0.581 \\
\hline $\mathbf{B 2}$ & 6 & 31.40 & 0.255 & 2352.60 & 8.12 & 19.099 & 0.499 \\
\hline $\mathbf{B 3}$ & 8 & 31.40 & 0.321 & 1485.29 & 10.22 & 15.175 & 0.092 \\
\hline
\end{tabular}

The welding system LWE03 was used, which is designed mainly for laser welding of thin rotary components (depth of the weld up to $0.6 \mathrm{~mm}$ ) with the possibility of setting the welding direction on the face or on the circumference of the rotary part. Some of the technical parameters of the used fiber laser welding system are: focal length of the lens $F$ is $150 \mathrm{~mm}$, shielding gas - Argon, diameter of the nozzle is $4 \mathrm{~mm}$ and diameter of the welded part can be up to $3 \mathrm{~mm}$. 
3.1 Evaluation of micropurity and microstructure of the weld samples

The term micropurity of steel includes the identification of the amount, number, size and distribution of inclusions of different chemical composition. Defects and pores in the root of the weld also occurred in the welds of the samples (Fig. 1). By evaluating the micropurity of the samples, oxides and carbonitrides in the microstructure were observed (Fig. 2).

The shape, quality and depth of welds were evaluated on the 12 samples produced with different values of welding parameters (Fig. 3 to 8). Defects also occur in the welded samples. On sample A4 (Fig. 4) there is a defect and samples A9, B1 and B2 contain pores in the root of the weld (Fig. 6, 7 and 8).

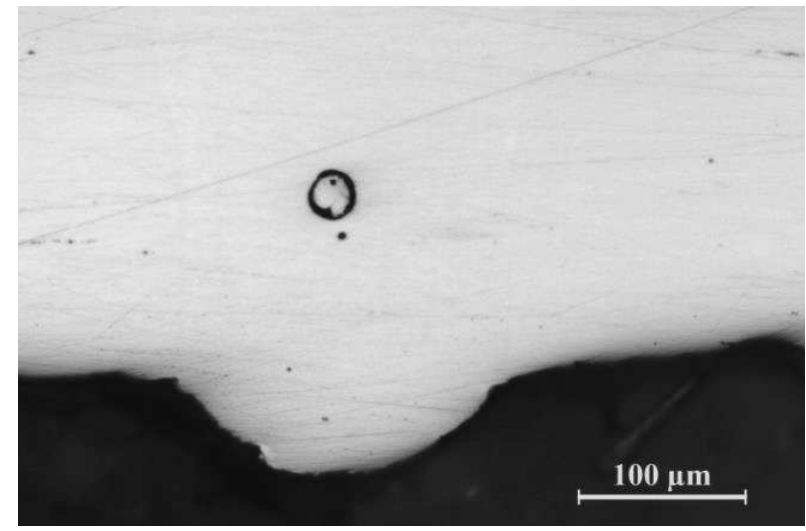

Fig. 1Micropurity of the weld of the sample B1and pore in weld

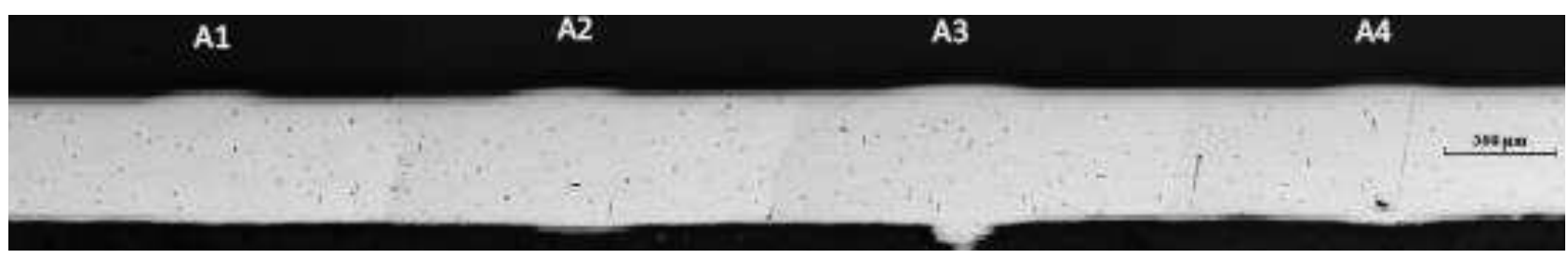

Fig. 2 Micropurity of the welds of the samples $A 1, A 2, A 3, A 4$
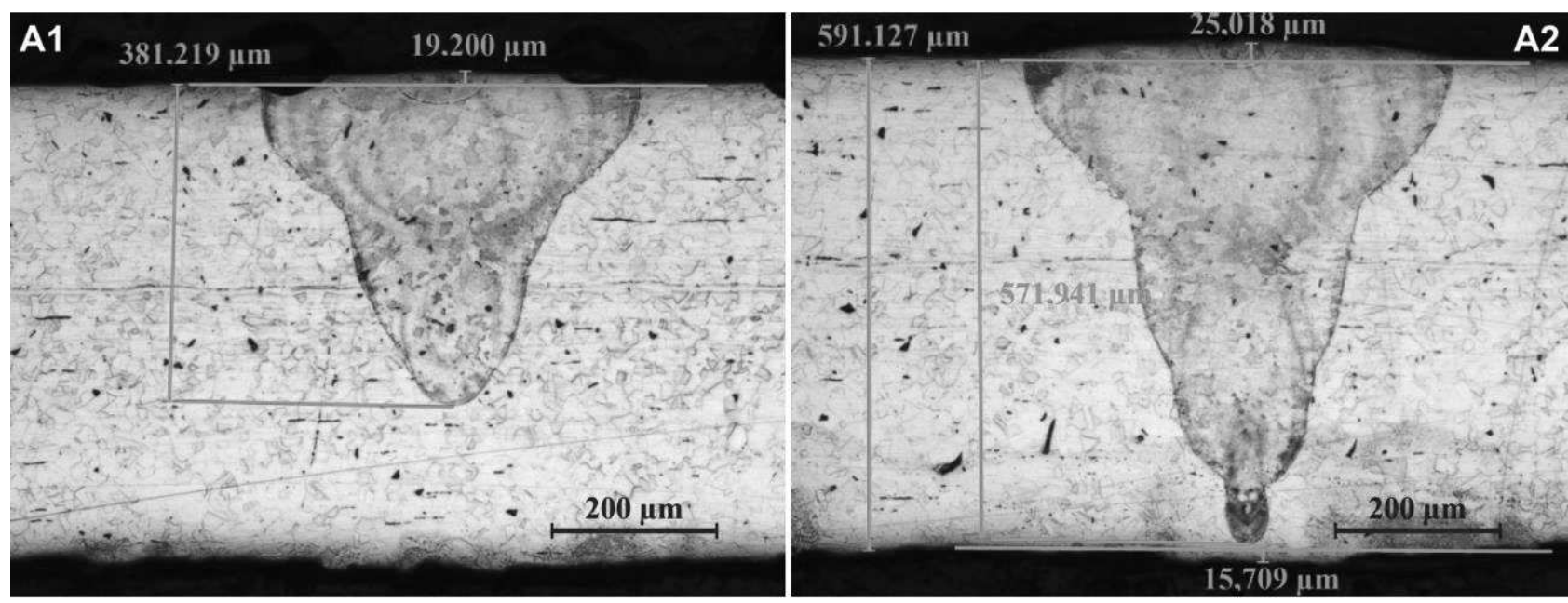

Fig. 3 Microstructures and dimensions of the welds of the samples $A 1$ and $A 2$
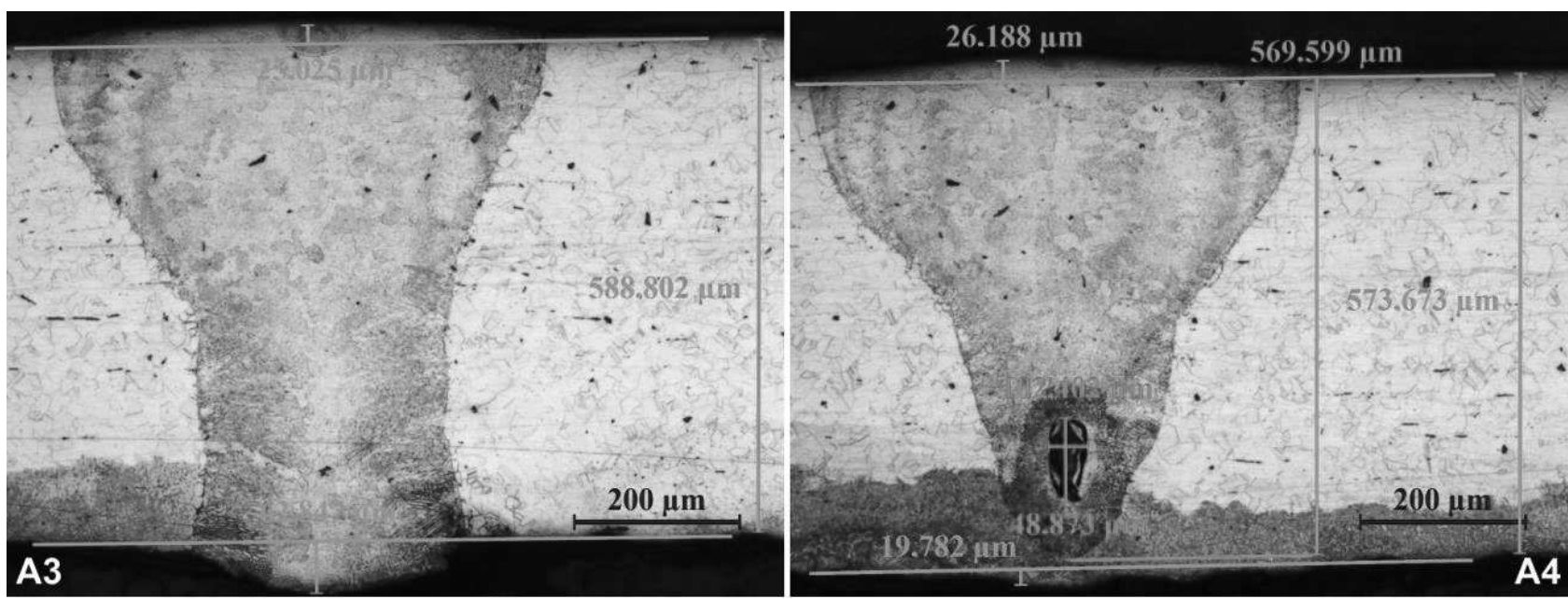

Fig. 4 Microstructures and dimensions of the welds of the samples $A 3$ and $A 4$ 

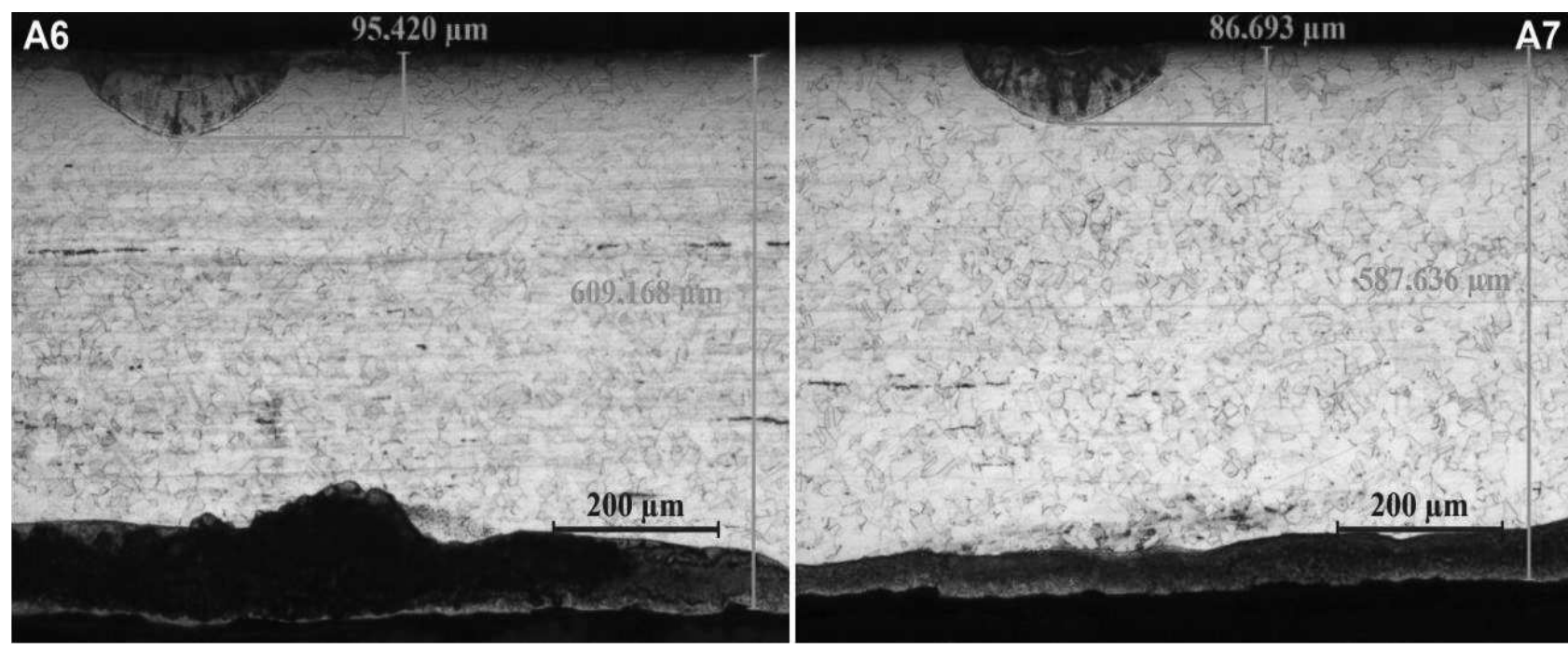

Fig. 5 Microstructures and dimensions of the welds of the samples $A 6$ and $A 7$
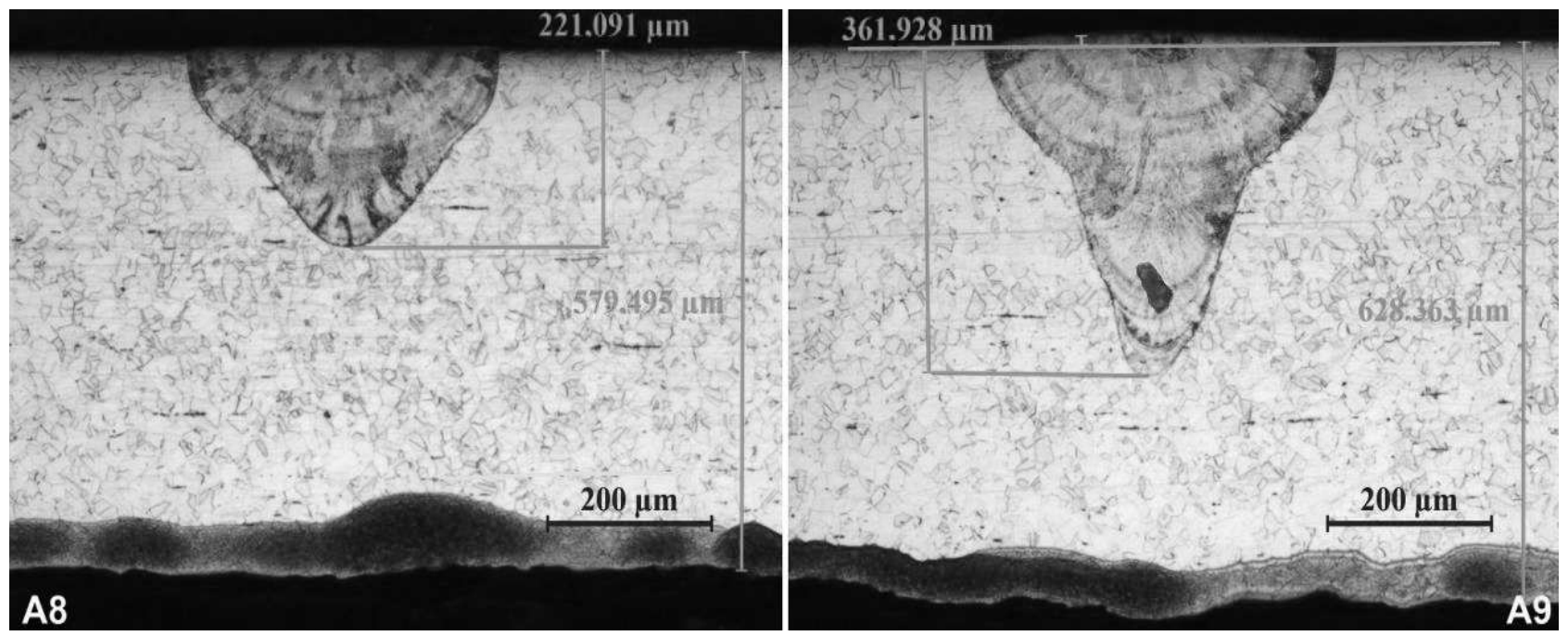

Fig. 6 Microstructures and dimensions of the welds of the samples $A 8$ and $A 9$
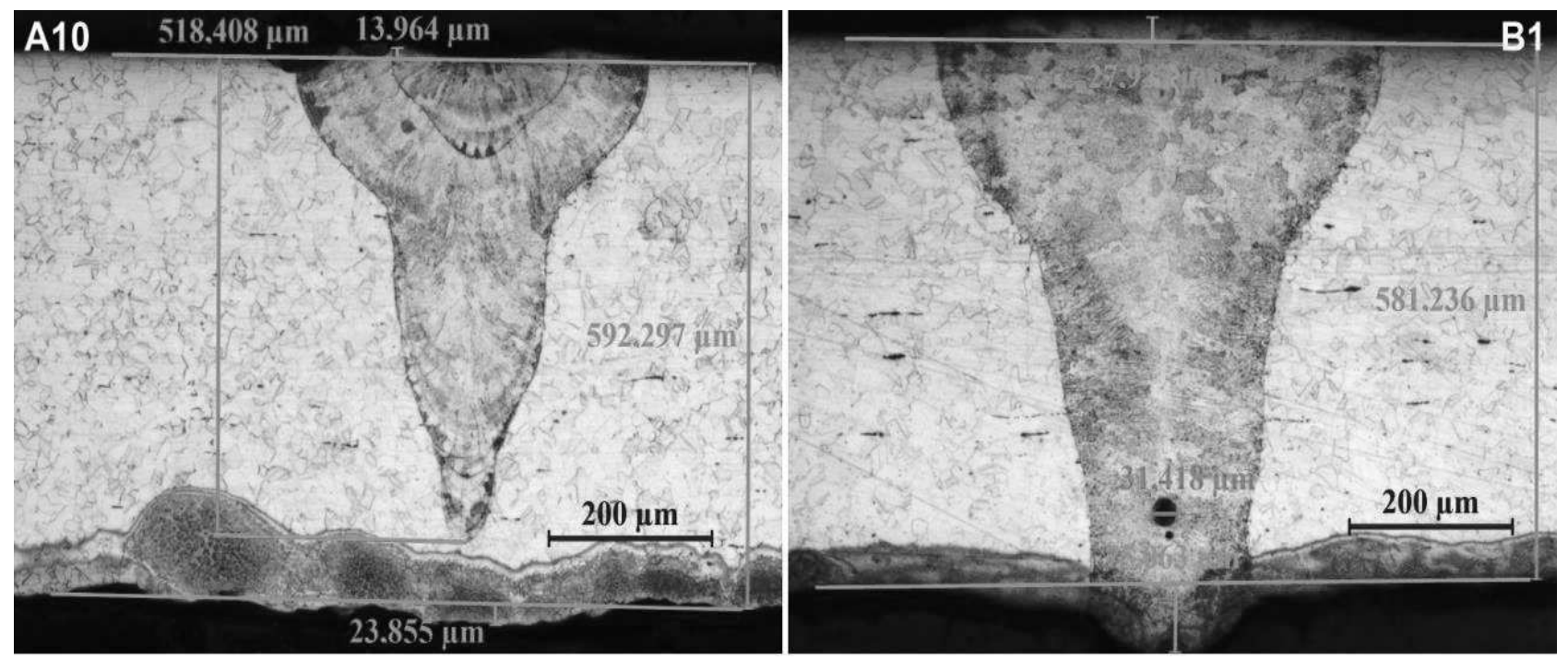

Fig. 7 Microstructures and dimensions of the welds of the samples $A 10$ and B1 

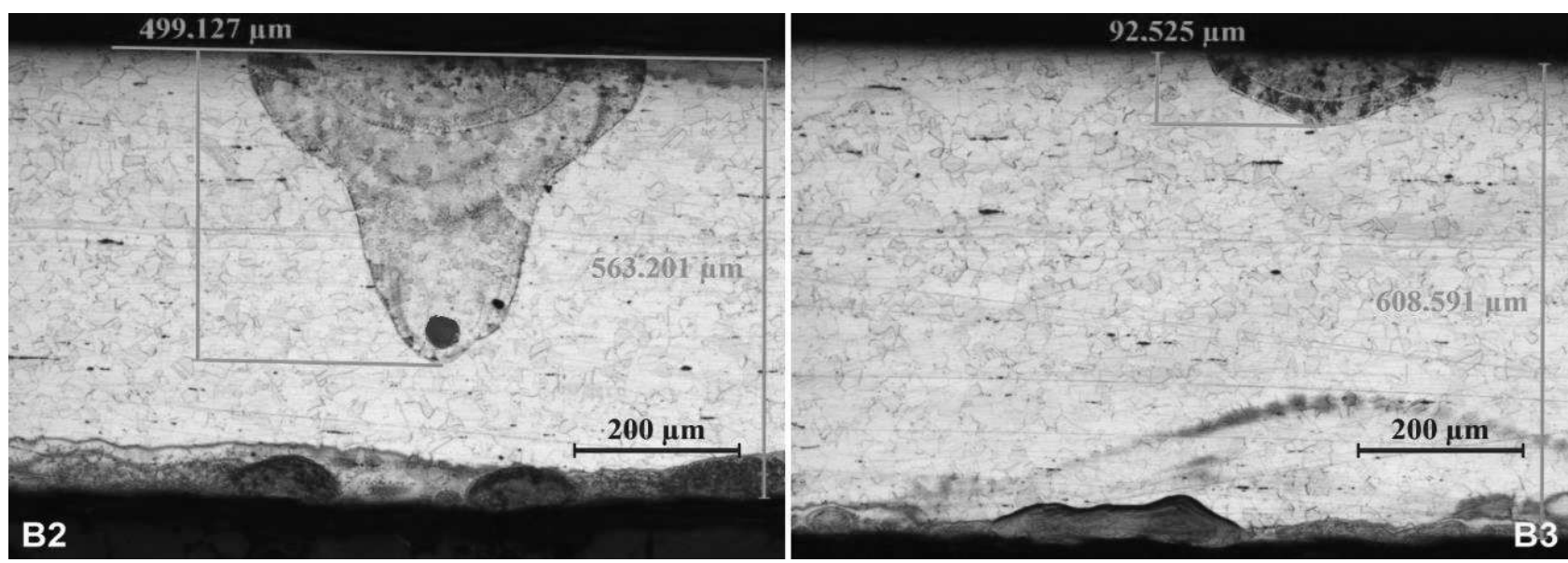

Fig. 8 Microstructures and dimensions of the welds of the samples B2 a B3

The optimal depth of the weld with respect to the wall thickness of the test tubes is approx. $0.4 \mathrm{~mm}$. Based on the evaluation of the shape, quality and depth of the weld, the sample A1 was evaluated as optimal.

The base material of steel X5CrNiMo17-12-2 (Fig. 9) was with significant deformation in the middle zone, the size of austenitic grains was $G=7$, we recorded twinning. The structure of the weld and the heat affected areas of sample A1 are shown in Fig. 10. The boundary of the interface of the weld with the base material was without significant grain orientation with the occurrence of precipitation.
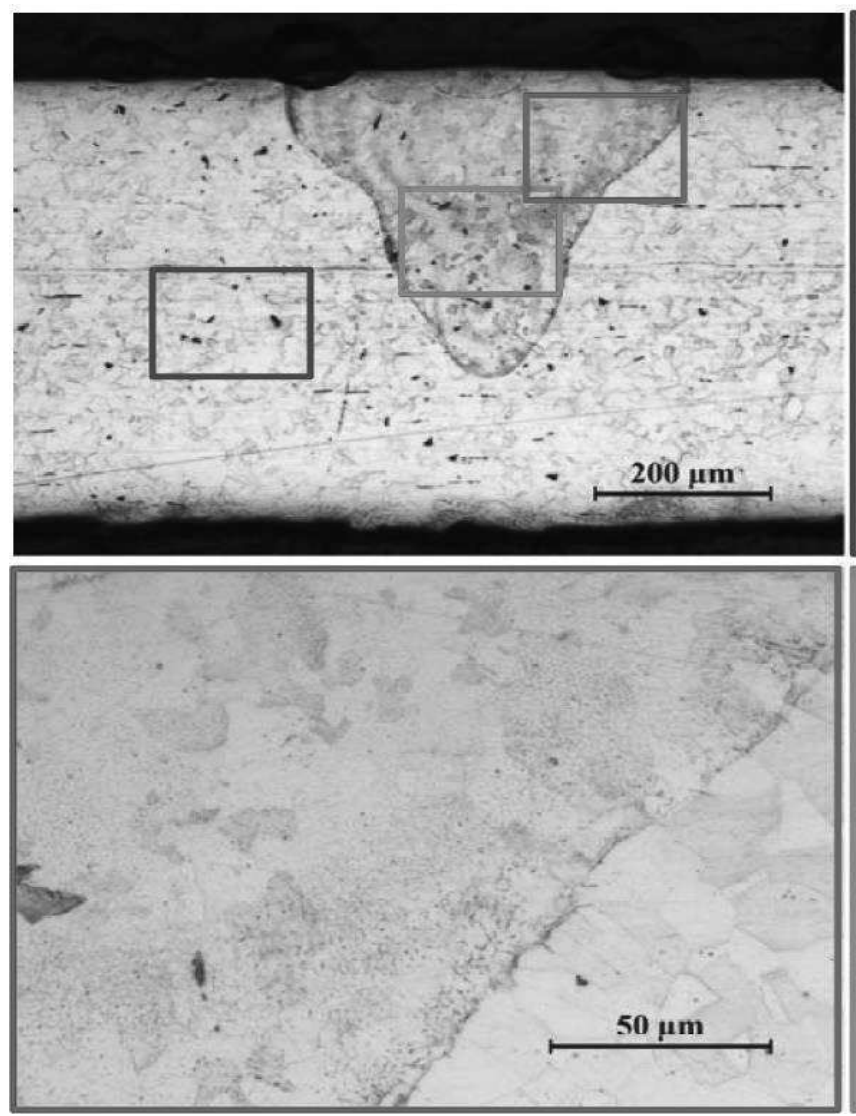

Fig. 10 Microstructures of the weld of the sample $A 1$

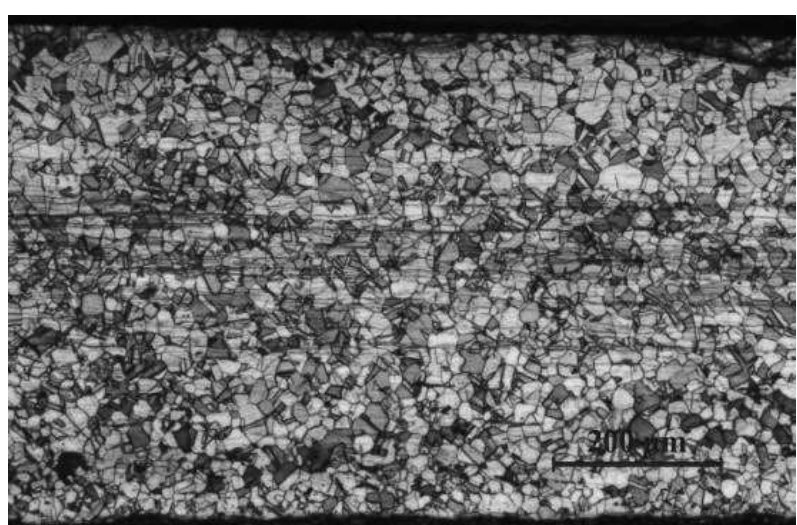

Fig. 9 Microstructure of base material

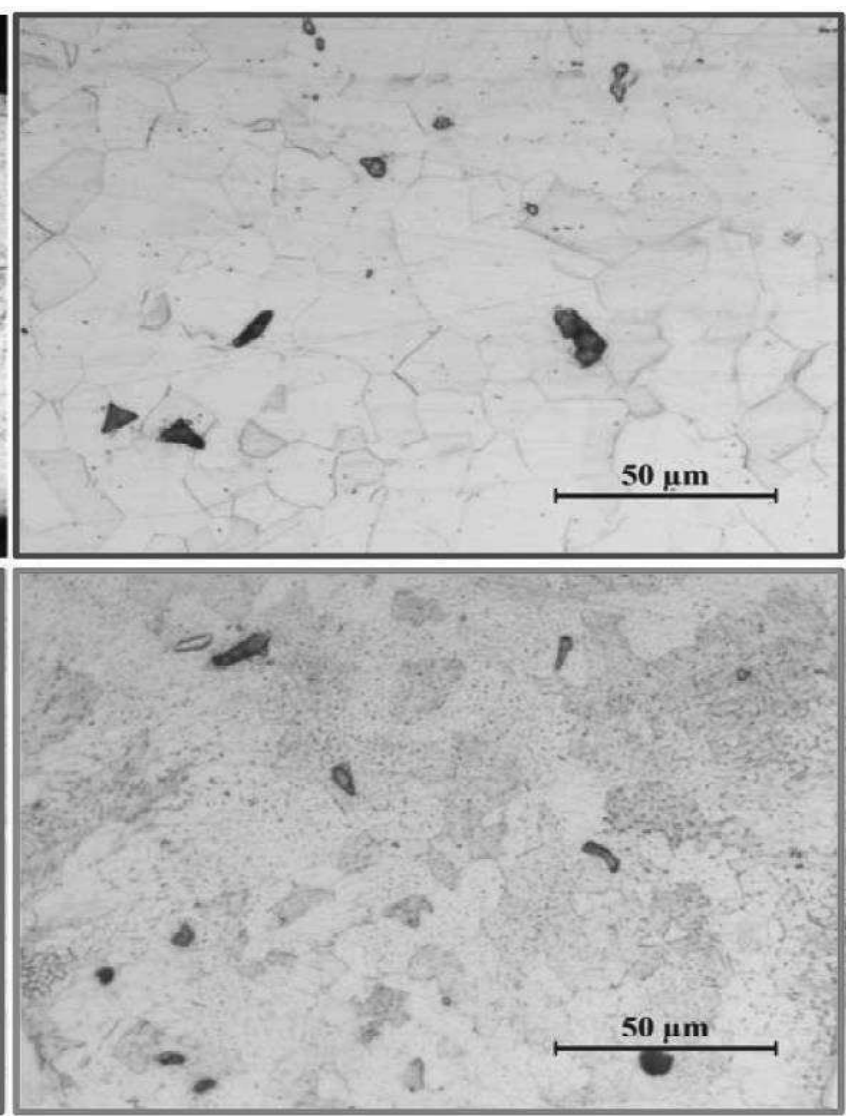

$$
1
$$


3.2 Evaluation of the macrostructure and the microstructures of the sample welds

Based on the evaluation of the shape, quality and required depth of the weld, optimal welding parameters was chosen those used for production of the sample A1 (Tab. 8). The chosen optimal parameters for welding a pair of tubes with a fiber laser are in Tab. 9. The sample of welded tubes - tube with outer diameter $2 \mathrm{~mm}$ inserted in tube with diameter $3 \mathrm{~mm}$ was labelled C1.

Tab. 9 setting of the welding system for welding of the sample C1

\begin{tabular}{|c|c|c|c|c|c|c|}
\hline $\begin{array}{c}\text { Sample } \\
\text { name }\end{array}$ & $\begin{array}{c}\text { Focal } \\
\text { location } \\
\mathbf{L}(\mathbf{m m})\end{array}$ & $\begin{array}{c}\text { Welding } \\
\text { speed } \\
\mathbf{v}_{\mathbf{z}}(\mathbf{m m} / \mathbf{s})\end{array}$ & $\begin{array}{c}\text { Beam } \\
\text { diameter } \\
\mathbf{d}_{\mathbf{L}}(\mathrm{mm})\end{array}$ & $\begin{array}{c}\text { Intensity } \\
\mathbf{I}_{\mathbf{m}} \\
\left(\mathbf{W} / \mathbf{m m}^{2}\right)\end{array}$ & $\begin{array}{c}\text { Time of } \\
\text { exposure } \\
\mathbf{t}(\mathbf{m s})\end{array}$ & $\begin{array}{c}\text { Energy } \\
\text { density } \\
\mathbf{E}_{\mathrm{m}}\left(\mathbf{J} / \mathbf{m m}^{2}\right)\end{array}$ \\
\hline $\mathbf{C 1}$ & 6 & 26.17 & 0.255 & 1960.50 & 9.74 & 19.099 \\
\hline
\end{tabular}

The outer tube has an austenitic matrix. Delta ferrite and tiny precipitates that were formed from the elements in the composition can be found there. Twinning was also observed. The inner tube is also similar to an austenitic structure, but probably there was another thermal effect and this caused the structure to be elongated. Ferrite can be found as well. There is a
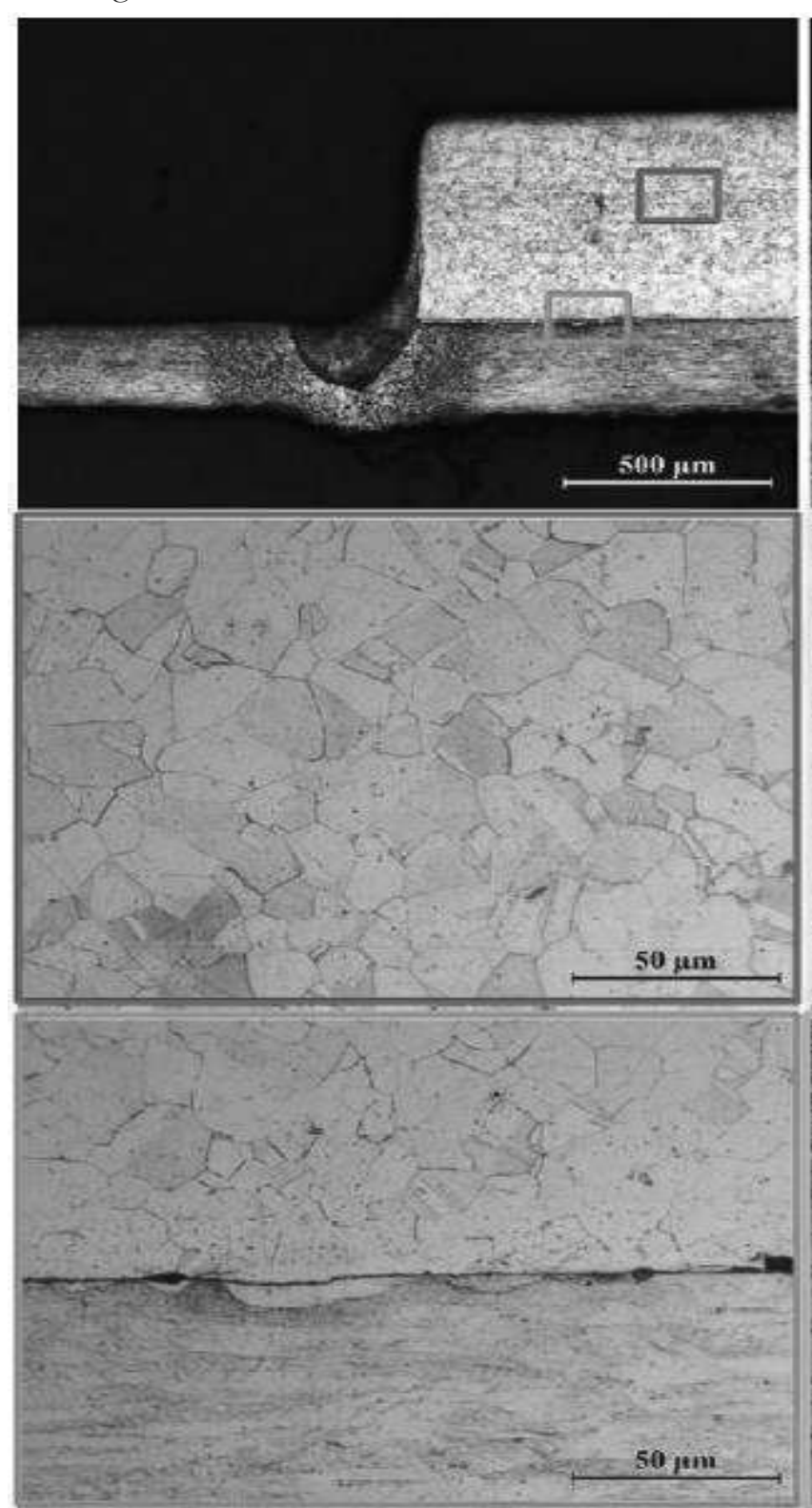

dendritic structure in the weld, which was created due to rapid cooling. It's uneven as it didn't cool the same way. The microstructures of the individual weld areas of sample $\mathrm{C} 1$ are shown in Fig. 11. The microstructure and dimensions of the heat-affected area of the weld C1 are shown in Fig. 12. The microstructure and depth of the weld of sample C1 are shown in Fig.13.
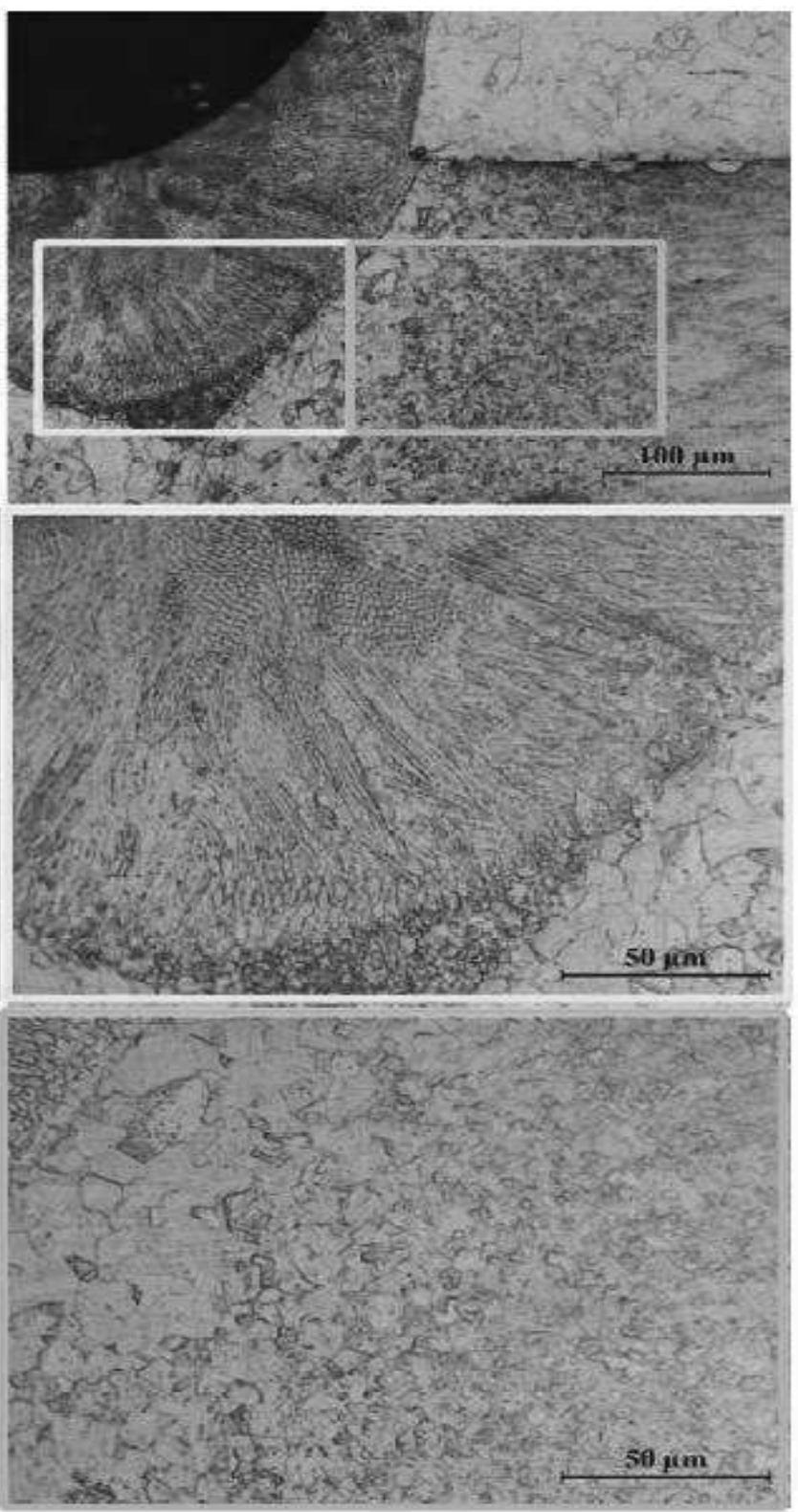

Fig. 11 Microstructures of areas of the weld of the sample C1 


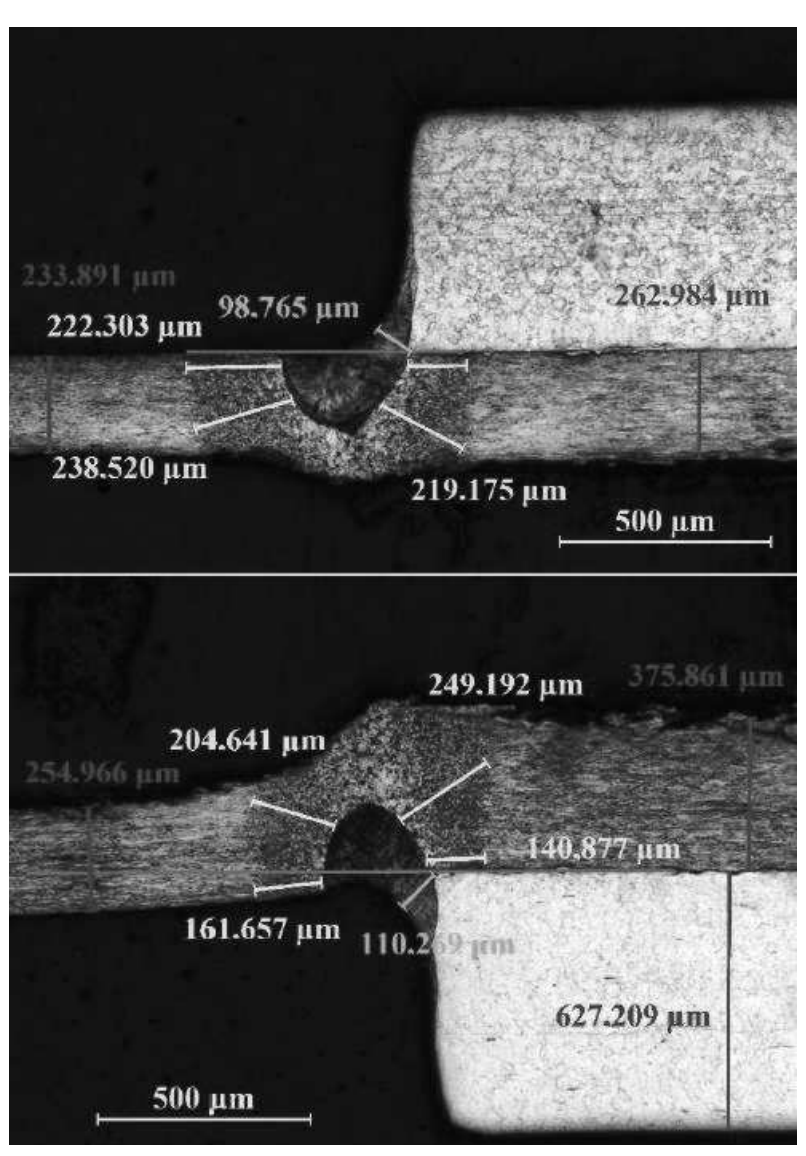

Fig. 12 Microstructure and dimensions of the heat-affected area of the weld of the sample C1

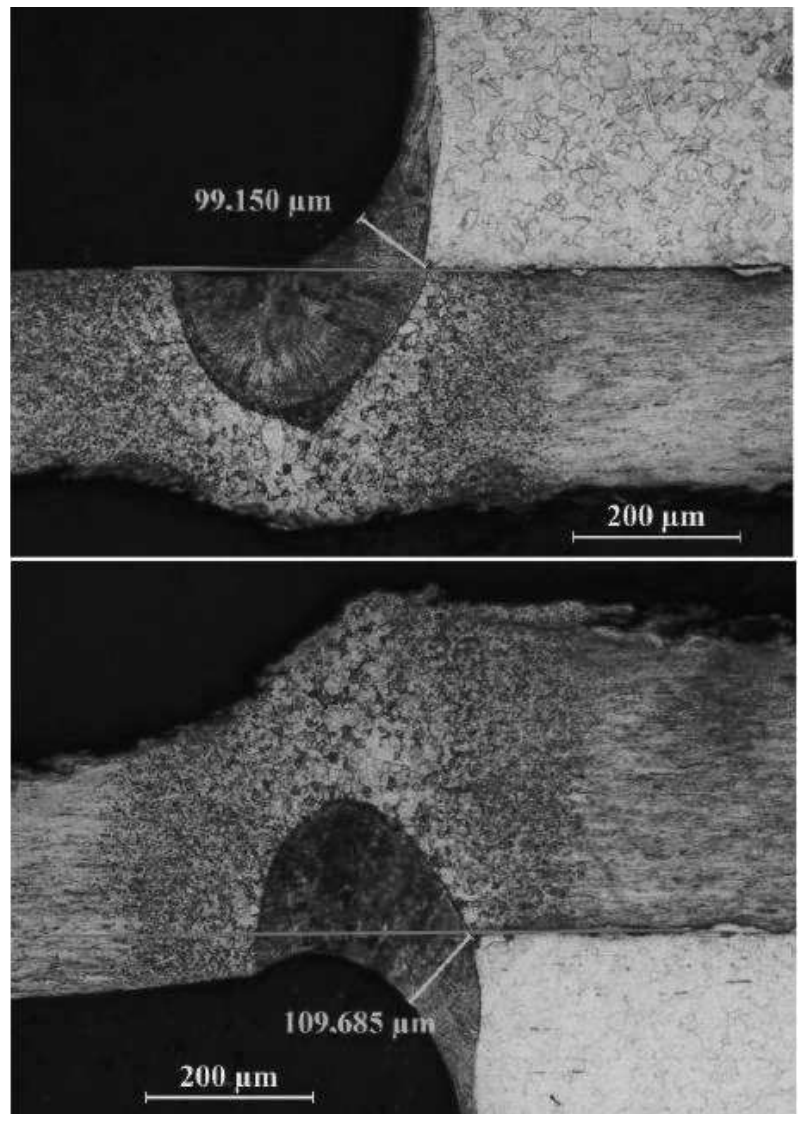

Fig. 13 Microstructure and depth of the weld of the sample C1
The achieved shape of the welded joint is different compared to the expected one (Fig.14). The direction of the laser beam is different from direction of the formed weld. This fact was probably caused by different thermal properties of both tubes and their geometric dimensions that influenced the different heat transfer in the tubes.

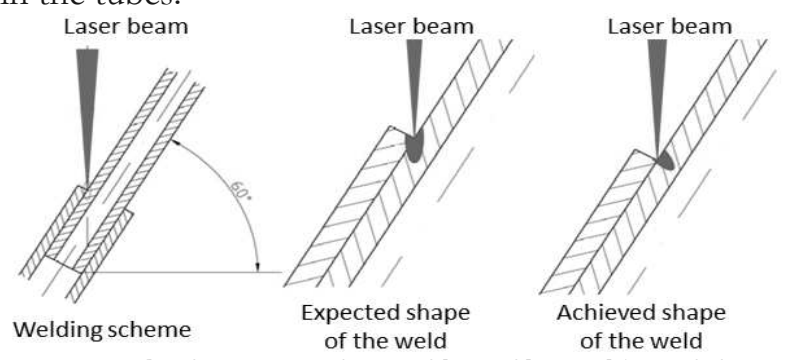

Fig. 14 Configuration scheme of laser fiber welding of the tubes

\subsection{Vickers microhardness test}

The hardness values were measured at 10 corners on the outer tube, the inner tube, in the weld and in the heat-affected area. The measurement on the samples was performed with a load of 200 grams. The injection time ranged from 8 to $10 \mathrm{~s}$. The hardness in the area of the welded joint did not show significant gradients. The hardness of the outer tube corresponded to the standard. The inner tube had a greater hardness than specified in the standard. During welding, the structure was probably thermally affected. The average Vickers microhardness values of the individual parts of the weld are given in Table 10.

Tab. 10 Average Vickers microhardness values of the sample C1

\begin{tabular}{|c|c|c|c|}
\hline \multicolumn{4}{|c|}{$\mathbf{H V}_{\mathbf{0}, 2}$} \\
\hline $\begin{array}{c}\text { Outer } \\
\text { tube }\end{array}$ & $\begin{array}{c}\text { Inner } \\
\text { tube }\end{array}$ & Weld & $\begin{array}{c}\text { Heat affec- } \\
\text { ted area }\end{array}$ \\
\hline $275 \pm 3$ & $665 \pm 5$ & $321 \pm 3$ & $404 \pm 10$ \\
\hline
\end{tabular}

\subsection{Tenile test}

Tests of the mechanical properties of construction materials and welding joints are an important tool for security and reliability control. The mechanical properties of welding joints were verified by a static tensile test. The samples were welded with a fiber laser with a rotary axis. Tube with a diameter of $2 \mathrm{~mm}$ was inserted into a tube with a diameter of $3 \mathrm{~mm}$ and welded circumferentially in the middle. The welding parameters are listed in Table 11. 20 samples were prepared:

- samples welded once around the circumference were marked D1 - D10,

- samples welded twice around the circumference were marked E1 - E10.

The average measured and calculated values from the static tensile test of samples D1 - D10 and E1 E10 are given in Table 12. 
Tab. 11 Parameter setting of the welding system for welding of the samples D1-D1 and E1-E10

\begin{tabular}{|c|c|c|c|c|c|c|}
\hline $\begin{array}{c}\text { Sample } \\
\text { name }\end{array}$ & $\begin{array}{c}\text { Focal } \\
\text { location } \\
\mathbf{L}(\mathbf{m m})\end{array}$ & $\begin{array}{c}\text { Welding } \\
\text { speed } \\
\mathbf{v}_{\mathbf{z}}(\mathbf{m m} / \mathbf{s})\end{array}$ & $\begin{array}{c}\text { Beam } \\
\text { diameter } \\
\mathrm{d}_{\mathrm{L}}(\mathbf{m m})\end{array}$ & $\begin{array}{c}\text { Intensity } \\
\mathbf{I}_{\mathbf{m}} \\
\left(\mathbf{W} / \mathbf{m m}^{2}\right)\end{array}$ & $\begin{array}{c}\text { Time of } \\
\text { exposure } \\
\mathbf{t}(\mathbf{m s})\end{array}$ & $\begin{array}{c}\text { Energy } \\
\text { density } \\
\mathbf{E}_{\mathbf{m}}\left(\mathbf{J} / \mathbf{m m}^{2}\right)\end{array}$ \\
\hline $\begin{array}{c}\text { D1 }-\mathbf{D 1 0} \\
\text { E1 }-\mathbf{E 1 0}\end{array}$ & 6 & 26.17 & 0.255 & 1960.50 & 9.74 & 19.099 \\
\hline
\end{tabular}

Tab. 12 Average measured and calculated values from the static tensile test of the samples D1 - D10 and E1 - E10

\begin{tabular}{|c|c|c|c|}
\hline Sample name & $\begin{array}{c}\text { Maximum force } \\
\mathbf{F}_{\mathrm{m}} \mathbf{( N )}\end{array}$ & $\begin{array}{c}\text { Tensile strength } \\
\left.\mathbf{R}_{\mathrm{m}} \mathbf{( M P a}\right)\end{array}$ & $\begin{array}{c}\text { Ductility } \\
\mathbf{A} \text { (\%) }\end{array}$ \\
\hline D1 $-\mathbf{D 1 0}$ & $458.5 \pm 3,8$ & $179.599 \pm 1.515$ & $0.91 \pm 0.02$ \\
\hline E1 $-\mathbf{E 1 0}$ & $571.3 \pm 3.2$ & $224,055 \pm 1.789$ & $0,84 \pm 0.02$ \\
\hline
\end{tabular}

The static tensile test shows that multiple welding increases the tensile strength. All tensile test specimens ruptured in the weld.

\section{Results and discussion}

The aim of the work was the analysis of selected steel materials welded by fiber laser. Two types of stainless steel tubes (X2CrNi19-11 and X5CrNiMo1712-2) were selected for experimental work. In the first stage, a sample of X5CrNiMo17-12-2 steel tubes was welded at different laser welding parameters. Metallographic cuts were performed on the samples and the geometric shape of the welds and their structure were documented. The results showed that by choosing technological parameters it is possible to achieve different depths of weld up to $0.588 \mathrm{~mm}$. In the next stage, a pair of tubes was fillet welded, while a tube made of X5CrNiMo17-12-2 steel was inserted into a tube made of X2CrNi19-11 steel. Welding parameters were selected based on the results of the welds in the first stage. The achieved welded joints were solid on the outside and without significant oxidation. However, metallographic cuts showed that the inner tube was more significantly melted in the welded joints, even though the laser beam was aimed more at the outer tube. A possible explanation for this result is the different heating of the thinner inner tube than the thicker outer one due to the different heat conduction of the tubes. By examining the micropurity, the presence of oxides and carbides were found. The microstructure of the outer tube showed an austenitic matrix with the occurrence of twinning, delta ferrite, small precipitates, which were part of material composition. During the fiber laser welding of the inner tube, a further thermal influence of the structure probably occurred, which caused the tube to stretch. In the heat-affected zone, there were a number of precipitates of chromium and molybdenum elements from the composition of material. There was a dendritic structure in the weld part due to uneven rapid cooling. Tensile tests of welded joints showed that in all cases the tubes ruptured in the welded joints. However, the results of double-welded welds showed that the weld strength was significantly increased.

\section{Conclusions}

The experiment was focused on determining suitable parameters of fiber laser welding of thin metal tubes made of X2CrNi19-11 and X5CrNiMo17-12-2. The main conclusions were summarized as follows:

- The constant parameters of the fiber laser that were used in the experimental work are: welding power, laser wavelength, beam parameter, focal length of the lens, beam diameter in front of the lens, beam diameter in the focal (Tab. 7)

- Samples were produced using different values of welding parameters: focal location, welding speed, beam diameter, intensity, time of exposure and energy density). Based on the evaluation of their microstructure, weld quality and depth of the weld with respect to the wall thickness of the welded tubes, optimal laser parameters were determined for welding two austenitic stainless steel tubes (Tab. 9).

- The structure of welded tubes was examined. The outer tube has an austenitic matrix with delta ferrite and tiny precipitates. Twinning was also observed. The inner tube has an austenitic structure, the structure is elongated. Ferrite can be found as well. There is a dendritic structure in the weld, which was created due to rapid cooling (Fig. 11 to 13).

- The tensile test shows that the specimens welded twice around the circumference have $25 \%$ greater strength than the specimens welded once around the circumference. All samples of the tensile test were torn in the weld (Tab. 12)

- The hardness of the outer tube complies with 
the standard. The inner tube has higher hardness than specified in the standard, which could be caused by the structure affected by heat treatment.

- The shape of the formed welding joint is different with respect to the direction of the laser beam. This fact was probably influenced by different thermal properties of the tubes and their geometric dimensions (Fig. 14).

The results presented in the work show that with a suitable choice of fiber laser welding parameters both aesthetic and strong welds of thin metallic materials can be achieved. Laser welding provides many advantages and enables easily achievable narrow and deep welding of a wide range of materials. Laser welding is realized with a very small energy input per unit of welded length, resulting in small deformations and low residual stress caused by welding and a small heat affected zone. The inertia of the laser beam is very small. High productivity of the technological process is achievable and laser welding is suitable for automation. Laser welding can be performed in an air atmosphere without the use of a vacuum or in an additional special inert atmosphere. There is no contamination of the weld with the electrode material. The laser beam can also weld hard-to-reach places that would be difficult to weld by other welding methods.

\section{Acknowledgement}

The contribution was supported by the Slovak grant project No. KEGA 002TnUAD - 4/2019. This publication was created in the frame of the project: Advancement and support of $R \& D$ for "Centre for diagnostics and quality testing of materials" in the domains of the RIS3 SK specialization, ITMS2014+:313011W442, based on the Operational Programme Integrated Infrastructure and funded from the European Regional Development Fund.

\section{References}

[1] ZRAK, A., TOFIL, S., ŠUTKA, J., MORAVEC, J. (2019). Impact of Technological Parameters of $\mathrm{CO}_{2}$ Laser Cutting on oxide adhesion forces on the Base Material. In: Manufacturing technology, Vol. 19, No. 6, pp. 1094 1099. DOI: 10.21062/ujep/423.2019/a/12132489/MT/19/6/1094. ISSN 1213-2489.

[2] HEYDARI, H., AKBARI, M. (2014). Investigating the effect of process parameters on the temperature field and mechanical properties in pulsed laser welding of Ti6Al4V alloy sheet using response surface methodology. In: Infrared Physics and Technology, Vol. 106. https://doi.org/10.1016/j.infrared.2020.103267. ISSN 1350-4495.

[3] LUKOVICS, I., MALACHOVÁ, M. (2007). Use of Laser in Engineering. In: Manufacturing Technology, Vol. 12, No. 13, pp. 26-31. ISSN 1213-2489.

[4] FARABI, N., CHEN, D.L., ZHOU, Y. (2011). Microstructure and mechanical properties of laser welded dissimilar DP600/DP980 dualphase steel joints. In: Journal of Alloys and Compounds, Vol. 509, Is. 3, pp. 982-989. https://doi.org/10.1016/j.jallcom.2010.08.158. ISSN 0925-8388.

[5] LANDOWSKI, M., ŚWIERCZYŃSKA, A., ROGALSKI, G., FYDRYCH, D. (2020). Autogenous fiber laser welding of 316L austenitic and 2304 lean duplex stainless steels. In: Materials, Vol. 13, Is. 13, pp. 2930. DOI: 10.3390/ma13132930. ISSN 1996-1944.

[6] SHANKAR, V., GILL, T. P. S., MANNAN, S. L., SUNDARESAN, S. (2003). Solidification cracking in austenitic stainless steel welds. In: Sadhana, Vol. 28, Is. 3-4, pp. 359-382. https://doi.org/10.1007/BF02706438. ISSN 0973-7677.

[7] MOHAMMED, G.R., ISHAK, M., AQIDA, S.N., ABDULHADI, H.A. (2017). Effects of heat input on microstructure, corrosion and mechanical characteristics of welded austenitic and duplex stainless steels: A review. In: Metals, Vol. 7, Is. 2, pp. 39 https://doi.org/10.3390/met7020039. ISSN 2075-4701.

[8] KURYNTSEV, S.V., GILMUTDINOV, A.K. (2015). Welding of stainless steel using defocused laser beam. In: Journal of Constructional Steel Research, Vol. 114, pp. 305-313. DOI: 10.1016/j.jcsr.2015.08.004. ISSN 0143-974X.

[9] KURYNTSEV, S.V. (2019). Effect of heat treatment on the phase composition and corrosion resistance of $321 \mathrm{SS}$ welded joints produced by a defocused laser beam. In: Materials, Vol. 12, Is. 22, pp. 3720. doi: 10.3390/ma12223720. ISSN 1996-1944.

[10] EL-BATAHGY, A.M. (1997). Effect of laser welding parameters on fusion zone shape and solidification structure of austenitic stainless steels. In: Materials letters, Vol. 32, Is. 2-3, pp. 155-163. https://doi.org/10.1016/S0167577X(97)00023-2. ISSN 0167-577X. 
[11] KUMAR, N., MUKHERJEE, M., BANDYOPADHYAY, A. (2017). Comparative study of pulsed Nd: YAG laser welding of AISI 304 and AISI 316 stainless steels. In: Optics \& Laser Technology, Vol. 88, pp. 24-39. https:// doi.org/10.1016/j.optlastec.2016.08.018. ISSN 0030-3992.

[12] BERRETTA, J. R., DE ROSSI, W., DAS NEVES, M.D.M., DE ALMEIDA, I. A., VIEIRA, N.D. (2007). Pulsed Nd: YAG laser welding of AISI 304 to AISI 420 stainless steels. In: Optics and Lasers in Engineering, Vol. 45, Is. 9, pp. 960-966. ISSN 0143-8166.

[13] KUMAR, N., MUKHERJEE, M., BANDYOPADHYAY, A. (2017). Study on laser welding of austenitic stainless steel by varying incident angle of pulsed laser beam. In: $O p$ tics \& Laser Technology, Vol. 94, pp. 296-309. https://doi.org/10.1016/j.optlastec.2017.04.008. ISSN 0030-3992.

[14] SATHIYA, P., PANNEERSELVAM, K., ABDUL JALEEL, M.Y. (2012). Optimization of laser welding process parameters for super austenitic stainless steel using artificial neural networks and genetic algorithm. In: Materials \& Design (1980-2015), Vol. 36, pp. 490-498. https:// doi.org/10.1016/j.matdes.2011.11.028. ISSN 0261-3069.

[15] TSIRKAS, S. A., PAPANIKOS, P., KERMANIDIS, TH. (2003). Numerical simulation of the laser welding process in butt-joint specimens. In: Journal of materials processing technology, Vol. 134, Is. 1, pp. 59-69. https://doi.org/10.1016/S0924-

0136(02)00921-4. ISSN 0924-0136.

[16] TAN, W., SHIN, Y.C. (2015). Multi-scale modeling of solidification and microstructure development in laser keyhole welding process for austenitic stainless steel. In: Computational Materials Science, Vol. 98, pp. 446 - 458. https://doi.org/10.1016/j.commatsci.2014.10.063. ISSN 0927-0256.

[17] SUDER, W. J., WILLIAMS, S. (2014). Power factor model for selection of welding parameters in CW laser welding. In: Optics \& Laser Technology, Vol. 56, pp. 223-229. https://doi.org/10.1016/j.optlastec.2013.08.016. ISSN 0030-3992.
[18] OLABI, A.G., ALSINANI, F.O., ALABDULKARIM, A.A., RUGGIERO, A., TRICARICO, L., BENYOUNIS, K.Y. (2013). Optimizing the $\mathrm{CO}_{2}$ laser welding process for dissimilar materials. In: Optics and Lasers in Engineering, Vol. 51, Is. 7, pp. 832-839. https://doi.org/10.1016/j.optlaseng.2013.01.024. ISSN 0143-8166.

[19] BENYOUNIS, K. Y., OLABI, A.G., HASHMI, M. S. J. (2008). Multi-response optimization of $\mathrm{CO}_{2}$ laser-welding process of austenitic stainless steel. In: Optics \& Laser Technology, Vol. 40, Is. 1, pp. 76-87. https://doi.org/10.1016/j.optlastec.2007.03.009. ISSN 0030-3992.

[20] MEŠKO, J., ZRAK, A., MULCYZK, K., TOFIL, S. (2014). Microstructure analysis of welded joints after laser welding. In: Manufacturing technology, Vol. 14, Is. 3, pp. 355-359. DOI: 10.21062/ujep/x.2014/a/12132489/MT/14/3/355. ISSN 1213-2489.

[21] RADEK, N., MEŠKO, J., ZRAK, A. (2014). Technology of laser forming. In: Manufacturing technology, Vol. 14, No. 3, pp. 428-431. DOI: 10.21062/ujep/x.2014/a/12132489/MT/14/3/428. ISSN 1213-2489.

[22] KRAUSS H., ZAEH, M. (2013). Investigations on Manufacturability and Process Reliability of Selective Laser Melting. In: Physics Procedia, Vol. 41, pp. 815-822. https://doi.org/10.1016/j.phpro.2013.03.153. ISSN 1875-3892.

[23] CHOWDHURYA, S., NIRSANAMETLAA, Y., MURALIDHARA, M., BAG, S., PAUL, C.P., BINDRACD, K.S. (2020). Identification of modes of welding using parametric studies during ytterbium fiber laser welding. In: Journal of Manufacturing Processes, Vol. 57, pp. 748-761. https://doi.org/10.1016/j.jmapro.2020.07.038 . ISSN 1526-6125.

[24] BENYOUNIS, Y., OLABI, A.G., HASHMIH, M.S.J. (2008). Multi-response optimization of $\mathrm{CO}_{2}$ laser-welding process of austenitic stainless steel. In: Optics \& Laser Technology, Vol. 40, Is. 1, pp. 76-87. ttps://doi.org/10.1016/j.optlastec.2007.03.009. ISSN 0030-3992. 